\title{
39. PETROLOGY OF HIGH-MgO BRONZITE ANDESITE RESEMBLING BONINITE FROM SITE 458 NEAR THE MARIANA TRENCH1, 2
}

\author{
I. Kushiro, Geological Institute, University of Tokyo, Tokyo 113, Japan
}

\begin{abstract}
A high-MgO andesite which is texturally similar to boninite and a variolitic basalt collected from Site 458 , about $100 \mathrm{~km}$ west of the Mariana Trench, have been studied through microprobe analyses and melting experiments at high water pressures. The boninite-type andesite is very similar in composition and texture to a boninite from Bonin Islands, except that the former is more calcic than the latter. The variolitic basalt contains magnesian pigeonite $\left(\mathrm{Ca}_{12} \mathrm{Mg}_{74} \mathrm{Fe}_{14}\right)$ in cores of augite microphenocrysts. This pigeonite crystallized at temperatures above $1200^{\circ} \mathrm{C}$. In the melting experiments of the boninite-type rock, clinopyroxene crystallizes as a liquidus phase at pressures at least above $8 \mathrm{kbar}$. No olivine crystallizes near the liquidus temperatures, indicating that the magma of this rock cannot be in equilibrium with the upper mantle periodotite (lherzolite) at depths at least greater than $25 \mathrm{~km}$. The boninite-type rock is probably a product of fractional crystallization of a more primitive magma (e.g., olivine-bearing boninite magma) by separation of olivine and orthopyroxene. The magma of the variolitic basalt also cannot be in equilibrium with the upper mantle peridotite, and may be a product of fractional crystallization of a more primitive basaltic magma.
\end{abstract}

\section{INTRODUCTION}

Recently boninite and magnesian andesite have drawn considerable interest because they possess certain characteristics of primary magmas formed in the upper mantle; that is, they have high $\mathrm{Mg} / \mathrm{Fe}$ ratios and high $\mathrm{Ni}$ and $\mathrm{Cr}$ contents and contain magnesian olivine and $\mathrm{Ca}$ poor pyroxene (bronzite or clinoenstatite). They are, however, significantly higher in $\mathrm{SiO}_{2}$ content than basalts with the same $\mathrm{MgO}$ contents or $\mathrm{Mg} / \mathrm{Fe}$ ratio. Such high $\mathrm{SiO}_{2}$ contents have been explained by the effect of $\mathrm{H}_{2} \mathrm{O}$ when they were formed in the upper mantle (Kushiro, 1972; Shiraki and Kuroda, 1977; Kay, 1978; and Kushiro and Sato, 1978). Presence of water in the fresh glass of boninite and coexistence of magnesian olivine and silica-rich glass (melt) without reaction strongly support this possibility.

Boninite was originally considered to be a very rare rock found only in the Bonin Islands, although similar rocks such as bronzite andesite and clinoenstatite-bearing andesitic rock have been reported in several localities including the Japanese and Aleutian Islands as well as Papua. The finding of boninitic and related rocks near the Mariana Trench during Leg 60 (Hussong, Uyeda et al., 1978) is significant because the conditions of generation of boninite magma occurred not just beneath the area of the Bonin Islands, but extended at least to the Mariana Trench in the middle Tertiary. However, before discussing this possibility, characterization of boninite from the Mariana fore-arc region must be made. In this short report, the petrographic character and melting relations at high water pressures of a boninite-type rock (Sample 458-28-1, 144-146 cm) are presented. A basaltic rock (Sample 458-29-1, 101-107 cm)

\footnotetext{
1 Initial Reports of the Deep Sea Drilling Project, Volume 60.

2 The author uses his own sample designations in this chapter; they are not to be confused with DSDP's conventional designation specifying core and section.
}

which is closely associated with the boninite has also been investigated for comparison. Although the boninitic rocks from Site 458 are probably more properly termed high- $\mathrm{MgO}$ andesite, or bronzite andesite (e.g., Site 458 report, this volume), for simplicity the sample of this composition investigated here will be called boninite.

\section{ROCK DESCRIPTIONS}

Sample 458-28-1, 144-166 is a bronzite-bearing andesitic rock and is very similar in texture to boninite from Bonin Islands, although no olivine is present. The rock consists of a small amount (a few percent) of phenocrysts and a groundmass of clear glass with numerous augite microlites. No plagioclase is present. Phenocrysts and microphenocrysts are augite $\left(\sim \mathrm{Ca}_{40} \mathrm{Mg}_{50} \mathrm{Fe}_{10}\right.$ on average $)$ and a small amount of bronzite $\left(\sim \mathrm{Ca}_{5} \mathrm{Mg}_{80} \mathrm{Fe}_{15}\right.$ on average). Most of the bronzite crystals are overgrown by augite. Thin magnesian pigeonite appears to be present between bronzite and augite in some grains. The orthopyroxene/clinopyroxene ratio is much less than that in typical boninites. The groundmass augite microlites are more iron-rich $\left(\sim \mathrm{Ca}_{37} \mathrm{Mg}_{48} \mathrm{Fe}_{15}\right)$ than the phenocryst augite, as shown in Figure 1.

The chemical composition of the rock determined by the conventional wet-chemical analysis method is given in Table 1 (Nos. 1 and 1a). The composition is also similar to that of a boninite from Bonin Islands (Nos. 2 and $2 \mathrm{a}$ ). However, the former is significantly higher in $\mathrm{CaO}$ than the latter. This difference reflects the difference in the orthopyroxene/clinopyroxene ratio and the liquidus relations of both the rocks.

Sample $458-29-1,101-107 \mathrm{~cm}$ is a variolitic basaltic rock, consisting of microphenocrysts of elongated clinopyroxene and groundmass of variolitic texture. Samples 458-29-1, 11-17 cm, 458-29-35, and 458-29-3, 3-8 cm are very similar in texture to it. No typical phenocrysts are present, indicating that the rocks would represent the 


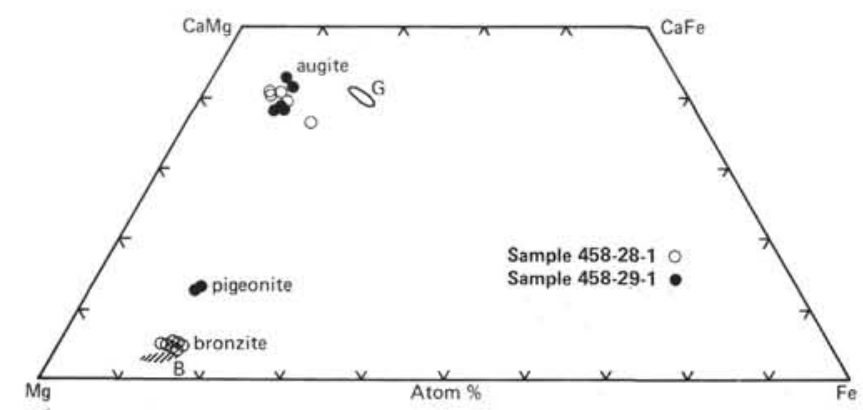

Figure 1. Compositions of pyroxenes in boninite (Sample 458-28-1) and variolitic basalt (Sample 458-29-1). Symbols: open circles = augite and bronzite phenocrysts in boninite (Sample 458-28-1); G $=$ groundmass augite in boninite (Sample 458-28-1); solid circles $=$ augite and pigeonite microphenocrysts in variolitic basalt (Sample 458-29-1); shaded area = bronzite in boninite from Bonin Island (Table 1, Nos. 2 and 2a) (Kushiro, unpublished data).

Table 1. Chemical compositions of boninite and basalt from Site 458.

\begin{tabular}{lrrrrrr}
\hline & \multicolumn{1}{c}{1} & \multicolumn{1}{c}{$1 \mathrm{a}$} & \multicolumn{1}{c}{2} & \multicolumn{1}{c}{$2 \mathrm{a}$} & \multicolumn{1}{c}{3} & \multicolumn{1}{c}{$3 \mathrm{a}$} \\
\hline $\mathrm{SiO}_{2}$ & 55.00 & 57.14 & 54.47 & 57.61 & 49.09 & 52.96 \\
$\mathrm{TiO}_{2}$ & 0.30 & 0.31 & 0.28 & 0.30 & 0.32 & 0.32 \\
$\mathrm{Al}_{2} \mathrm{O}_{3}$ & 13.90 & 14.44 & 14.97 & 15.83 & 15.90 & 17.16 \\
$\mathrm{Fe}_{2} \mathrm{O}_{3}$ & 1.34 & 1.39 & 0.68 & 0.72 & 4.74 & 5.11 \\
$\mathrm{FeO}$ & 6.22 & 6.46 & 6.11 & 6.46 & 2.84 & 3.06 \\
$\mathrm{MnO}$ & 0.14 & 0.15 & 0.15 & 0.16 & 0.11 & 0.12 \\
$\mathrm{MgO}$ & 6.88 & 7.15 & 8.08 & 8.55 & 7.36 & 7.94 \\
$\mathrm{CaO}$ & 10.19 & 10.59 & 7.36 & 7.78 & 9.14 & 9.86 \\
$\mathrm{Na}_{2} \mathrm{O}$ & 1.83 & 1.90 & 1.77 & 1.87 & 2.15 & 2.32 \\
$\mathrm{~K}_{2} \mathrm{O}$ & 0.38 & 0.39 & 0.66 & 0.70 & 0.94 & 1.01 \\
$\mathrm{H}_{2} \mathrm{O}^{(-)}$ & 0.44 & - & 0.64 & - & 4.42 & - \\
$\mathrm{H} \mathrm{O}^{(+)}$ & 3.38 & - & 5.00 & - & 2.65 & - \\
$\mathrm{P}_{2} \mathrm{O}_{5}$ & 0.07 & 0.07 & 0.02 & 0.02 & 0.12 & 0.13 \\
$\mathrm{Total}$ & 100.07 & 99.99 & 100.19 & 100.00 & 99.76 & 100.00 \\
$\mathrm{Norm}$ & & & & & & \\
$\mathrm{Q}$ & & 11.54 & & 10.89 & & 5.69 \\
or & & 2.28 & & 4.12 & & 5.96 \\
ab & & 16.10 & & 15.83 & & 19.61 \\
an & & 29.71 & & 32.74 & & 33.44 \\
wo & & 9.32 & & 2.40 & & 6.11 \\
en & & 17.80 & & 21.29 & & 19.77 \\
fs & & 10.48 & & 11.07 & & 1.10 \\
il & & 0.59 & & 0.58 & & 0.61 \\
mt & & 2.01 & & 1.04 & & 7.41 \\
ap & & 0.16 & & 0.03 & & 0.30 \\
\hline
\end{tabular}

Notes:

1 and $1 \mathrm{a}=$ Boninite (Sample 458-28-1, 144-146 cm) from Site 458. Analyst: H. Haramura.

2 and $2 \mathrm{a}=$ Boninite from Chichi-jima, Bonin Islands (Shiraki and Kuroda, 1977).

3 and $3 \mathrm{a}=$ Basalt (Sample 458-29-1, 101-107 cm) from Site 458. Analyst: $H$. Haramura.

$1 \mathrm{a}, 2 \mathrm{a}$, and $3 \mathrm{a}$ are recalculated to $100 \%$ on an anhdrous basis.

magmas from which they solidified. Many clinopyroxene microlites and thin plagioclase laths with radial texture are present in the groundmass. No discrete orthopyroxene crystals have been found in the thin sections examined of Sample 458-29-1, 101-107 cm. Microprobe analysis shows that most of the clinopyroxenes are augite $\left(\mathrm{Ca}_{40} \mathrm{Mg}_{50} \mathrm{Fe}_{10}\right.$ on average). Magnesian pigeonite $\left(\sim \mathrm{Ca}_{12} \mathrm{Mg}_{74} \mathrm{Fe}_{14}\right)$ (Fig. 1) was found in the core of some relatively large augite microphenocrysts. Such magnesian pigeonite is extremely rare in terrestrial igneous rocks. It must have been crystallized at high temperatures, as subsequently discussed. Most of the clinopyroxene crystals have hollow centers and are quite imperfect, probably due to rapid growth of the crystals.

The chemical composition of Sample 458-29-1, 101$107 \mathrm{~cm}$ (Table 1, Nos. 3 and 3a), determined by the conventional wet-chemical analysis method, is significantly lower in $\mathrm{SiO}_{2}$ and higher in $\mathrm{CaO}$ than that of boninites with similar $\mathrm{MgO}$ contents. More than 5 percent normative quartz is calculated, but this rock is considerably oxidized and when all $\mathrm{Fe}_{2} \mathrm{O}_{3}$ is reduced to $\mathrm{FeO}$, normative quartz disappears. In addition, this rock does not contain orthopyroxene, but contains plagioclase and its texture is unlike that of boninite. For these reasons, we do not call this rock boninite, but instead we call it variolitic basalt. The composition is high in $\mathrm{Al}_{2} \mathrm{O}_{3}$ and it falls within the field of high-alumina basalts when plotted in the ternary $\mathrm{Al}_{2} \mathrm{O}_{3}-\left(\mathrm{K}_{2} \mathrm{O}+\right.$ $\left.\mathrm{Na}_{2} \mathrm{O}\right)-\mathrm{SiO}_{2}$ diagram of Kuno (1960).

\section{MELTING EXPERIMENTS UNDER HYDROUS CONDITIONS}

Preliminary experiments have been carried out on the boninite (Sample 458-28-1) and the basalt (Sample 458-29-1) at pressures between 8 and 14.5 kbar under hydrous conditions. The water content ranges from 10 to 22 weight percent. These water contents are for near saturation or oversaturation with water in andesite melts (Sakuyama and Kushiro, 1979). Sealed $\mathrm{Ag}_{70} \mathrm{Pd}_{30}$ capsules were used for all the runs. The loss of iron to the AgPd capsules was almost negligible even during 18-hour runs at $1050^{\circ} \mathrm{C}$; the glass after the run still contains 7.61 weight percent $\mathrm{FeO}$, compared to 7.71 weight percent in the starting material. All the runs were made with solid-media, piston-cylinder type apparatus.

The results of the runs are given in Table 2. For boninite Sample 28-1 clinopyroxene is the liquidus phase in the pressure range between 8 and $12.5 \mathrm{kbar}$ in the presence of excess $\mathrm{H}_{2} \mathrm{O}$. The composition of clinopyroxene crystallized near the liquidus is nearly the same as that of the cores of phenocryst augite in the rock. At $14.5 \mathrm{kbar}$, both clinopyroxene and orthopyroxene are present, but the amount of orthopyroxene is much less than that of clinopyroxene, and it is most likely that clinopyroxene is the liquidus phase at this pressure. Olivine does not crystallize in any of the runs made on boninite (Sample 458-28-1). Boninite from Bonin Islands (Table 1, Nos. 2 and $2 \mathrm{~b}$ ) shows different melting relations; orthopyroxene is the liquidus phase above 11 kbar (Kushiro, unpublished data). The difference is most probably due to the difference in $\mathrm{Ca}$ content in these two boninites as shown above.

For basalt (Sample 458-29-1) clinopyroxene is the liquidus phase at $13 \mathrm{kbar}$, but at $11 \mathrm{kbar}$ clinopyroxene and a very small amount of olivine are present, although the latter has not been confirmed by electron microprobe analysis. No orthopyroxene occurs in these runs. 
Table 2. Results of the tests made on boninite Sample 458-28-1 and variolitic basalt Sample 458-29-1, from Site 458.

\begin{tabular}{|c|c|c|c|c|}
\hline $\begin{array}{l}\text { Pressure } \\
\text { (kbar) }\end{array}$ & $\begin{array}{l}\text { Temperature } \\
\left({ }^{\circ} \mathrm{C}\right)\end{array}$ & $\begin{array}{c}\text { Time } \\
(\mathrm{hr})\end{array}$ & $\begin{array}{l}\mathrm{H}_{2} \mathrm{O} \\
\text { (wt.\%) }\end{array}$ & Products \\
\hline \multicolumn{5}{|c|}{ Boninite } \\
\hline 8 & 1075 & 9 & 10.3 & $\mathrm{Cpx}+\mathrm{gl}+\mathrm{q}$-cryst \\
\hline 9.5 & 1075 & 9 & 14.0 & Cpx(rare) $+\mathrm{gl}+\mathrm{q}$-cryst \\
\hline 10.5 & 1050 & 18.5 & 14.0 & $\begin{array}{l}\mathrm{Cpx}\left(\mathrm{Ca}_{39.1} \mathrm{Mg}_{51.3} \mathrm{Fe}_{2.6}\right)+\mathrm{opx} \\
+\mathrm{gl}+\mathrm{q} \text {-cryst }\end{array}$ \\
\hline 10.5 & 1050 & 18.5 & 18.9 & $\begin{array}{l}\mathrm{Cpx}\left(\mathrm{Ca}_{41} .6 \mathrm{Mg}_{49.7} \mathrm{Fe}_{8.7}\right)+\mathrm{gl} \\
+ \text { q-cryst }\end{array}$ \\
\hline 11 & 1075 & 20 & 14.5 & $\mathrm{Cpx}+\mathrm{gl}+\mathrm{q}$-cryst \\
\hline 11 & 1075 & 20 & 18.8 & $\mathrm{Cpx}+\mathrm{gl}+\mathrm{q}$-cryst \\
\hline 12.5 & 1050 & 6 & 10.0 & $\begin{array}{l}\mathrm{Cpx}\left(\mathrm{Ca}_{36.6} \mathrm{Mg}_{52.8} \mathrm{Fe}_{10.5}\right)+ \\
\text { opx }\left(\mathrm{Ca}_{4} . \mathrm{Mg}_{81.8} \mathrm{Fe}_{13.9}\right)+\mathrm{gl}\end{array}$ \\
\hline 12.5 & 1050 & 6 & 15.4 & $\begin{array}{l}\mathrm{Cpx}+\text { opx }\left(\mathrm{Ca}_{4} .4 \mathrm{Mg}_{79.9} \mathrm{Fe}_{15.7}\right) \\
+\mathrm{gl}+\text { q-cryst }\end{array}$ \\
\hline 12.5 & 1050 & 6 & 21.1 & $\mathrm{Cpx}+\mathrm{gl}+\mathrm{q}$-cryst \\
\hline 14.5 & 1025 & 1 & 13.8 & $\mathrm{Cpx}+\mathrm{opx}+\mathrm{gl}+\mathrm{q}$-cryst \\
\hline \multicolumn{5}{|c|}{ Basalt } \\
\hline 11 & 1000 & 2 & 12.4 & $\mathrm{Cpx}+\mathrm{ol}+\mathrm{gl}+\mathrm{q}$-cryst \\
\hline 12 & 1020 & 2 & 14.3 & $\mathrm{Gl}+$ q-cryst \\
\hline 13 & 1000 & 3 & 12.9 & $\mathrm{Cpx}+\mathrm{gl}+\mathrm{q}$-cryst \\
\hline
\end{tabular}

The results of the experiments indicate that the magma of boninite Sample 458-28-1 cannot be in equilibrium with the upper mantle peridotite (or olivine + orthopyroxene + clinopyroxene + spinel or garnet assemblage) at least above $8 \mathrm{kbar}(>25 \mathrm{~km}$ depth) under hydrous conditions. At higher pressures the field of clinopyroxene expands, and clinopyroxene would continue to be the liquidus phase. Under anhydrous conditions or with smaller amounts of water, such silica-rich magnesian magma cannot be in equilibrium with magnesian olivine. It is most likely that the magma of boninite Sample 458-28-1 has been fractionated by separation of olivine and orthopyroxene at relatively shallow depths. The original magma may be more enriched in olivine and orthopyroxene components (i.e., higher in $\mathrm{MgO}$ and lower in $\mathrm{CaO}$ ) and closer in composition to olivine-bearing typical boninite.

The magma of basalt Sample 458-29-1 can be in equilibrium with olivine and clinopyroxene at pressures at least at 11 kbar under hydrous conditions. However, it cannot be in equilibrium with upper mantle peridotite (lherzolite). If the water content in the magma is lower, orthopyroxene would crystallize, but at the same time the field of olivine crystallization would be reduced. I suggest that the magma of this basalt may also be a product of fractional crystallization of a more primitive basaltic magma. The genetic relationship between boninite and variolitic high-alumina basalt is an interesting problem. One possibility is that the original magma of the boninite was formed in the upper mantle under conditions of excess or nearly excess water, whereas that of the basalt was formed under water-undersaturated or nearly dry conditions from the same source region.

The basalt Sample 458-29-1 contains magnesian pigeonite in the cores of augite microphenocrysts. As this magnesian pigeonite most probably crystallized from magma as a stable phase, the temperature of its crystallization would have been higher than $1200^{\circ} \mathrm{C}$ according to the "pigeonite geothermometer" of Ishii (1975). The original magma, therefore, must have been formed at temperatures higher than $1200^{\circ} \mathrm{C}$. If the site of generation of this magma was above the subducted oceanic plate, the geotherm below Site 458 , about $100 \mathrm{~km}$ from the present trench, must have been fairly steep, at least steeper than that in the present island arc, at the time of magma generation.

\section{ACKNOWLEDGMENTS}

The author thanks Prof. S. Uyeda and Dr. J. Natland for the samples of Leg 60 used in the present studies, and Prof. S. Aramaki and Dr. T. Fujii of the University of Tokyo for critical reading of the manuscript.

\section{REFERENCES}

Hussong, D., Uyeda, S., et al., 1979. Initial Core Descriptions for DSDP Leg 60, 1978.

Ishii, T., 1975. The relations between temperature and composition of pigeonite in some lavas and their application to geothermometry. Mineral. J., 8:48-57.

Kay, R. W., 1978. Aleutian magnesian andesites: melts from subducted Pacific ocean crust. J. Volcanol. Geotherm. Res., 4: 117-132.

Kuno, H., 1960. High-alumina basalt. J. Petrol., 1:121-145.

Kushiro, I., 1972. Effect of water on the composition of magmas formed at high pressures. J. Petrol., 13:311-334.

Kushiro, I., and Sato, H., 1978. Origin of calc-alkalic andesite in Japanese Islands-Critical review and discussion. Abstract International Geodynamics Conference, Western Pacific and Magma Genesis, Tokyo, 1978, p. 284-285.

Sakuyama, M., and Kushiro, I., 1979. Vesiculation of hydrous andesitic melt and transport of alkalies by separated vapor phase. Contrib. Mineral. Petrol., 71:61-66.

Shiraki, K., and Kuroda, N., 1977. The boninite revisited (in Japanese with English abstract). J. Geogr., 86:34-50. 